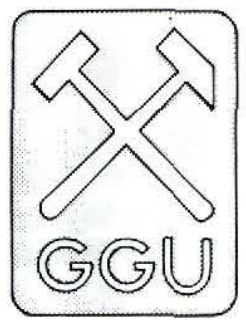

\title{
A second glimpse of Early Cambrian life: new collections from Sirius Passet, North Greenland
}

\author{
John S. Peel, Simon Conway Morris \\ and Jon R. Ineson
}

The German mining term lagerstätten, referring to a rock of any composition containing constituents of economic interest, has been widely applied to occurrences of abundant or unusually well preserved fossils (cf. Seilacher et al., 1985). The Middle Cambrian Burgess Shale of western Canada is perhaps the most famous of all fossil-lagerstätte, with many of the approximately 140 known species preserving exquisite details of the soft anatomy of members of a community of organisms that was fossilised more than 500 million years ago (Whittington, 1985; Conway Morris, 1979, 1986; Gould, 1989). Other well known examples include the Upper Cambrian 'Orsten' of southern Sweden, the Lower Devonian Hunsrück Slate and the Jurassic Solnhofen Limestone of Germany (Stürmer et al., 1980; Müller, 1985; Barthel et al, 1990; summary in Briggs \& Crowther, 1990, pp. 266-297). The term can be applied aptly to the Sirius Passet fauna of central North Greenland, where a wealth of exceptionally preserved fossils (e.g. Fig. 1) from the Lower Cambrian Buen Formation has been recorded from a small locality in western Peary Land, near the south-western end of the broad valley known as Sirius Passet (Fig. 2).

The locality yielding the Sirius Passet fauna was discovered in 1984, but substantial collecting was first possible in 1989 (Conway Morris et al., 1987; Conway Morris \& Peel, 1990; Peel, 1990). At that time, a collection of some 1500 slabs of mudstone was secured, yielding a fauna of more than 30 species. Interest in the Sirius Passet fauna reflects not only the anatomical information which can be derived from specimens preserving details of limbs and soft parts, but also the great antiquity of the locality. The assemblage is significantly older than the Burgess Shale lagerstätten of Canada, and of

Fig. 1. Articulated halkieriid from the Buen Formation at Sirius Passet, central North Greenland, MGUH 19.728 from GGU collection $340103, \times 2$. The worm-like body is covered by many hundreds of small sclerites, with prominent shells located anteriorly (turned to the right in this specimen) and posteriorly. similar age to the Chengjiang fauna of Yunnan Province, China (Chen Jun-yuan \& Erdtmann, 1991; Chen Jun-yuan et al., 1991; Hou Xian-guang \& Bergström, 1991).

The most noteworthy members of the Sirius Passet fauna are articulated halkieriid worms (Fig. 1; Conway Morris \& Peel, 1990; Peel, 1991), but the arthropoddominated fauna also yields sponges, worms and several organisms of problematic affinities.

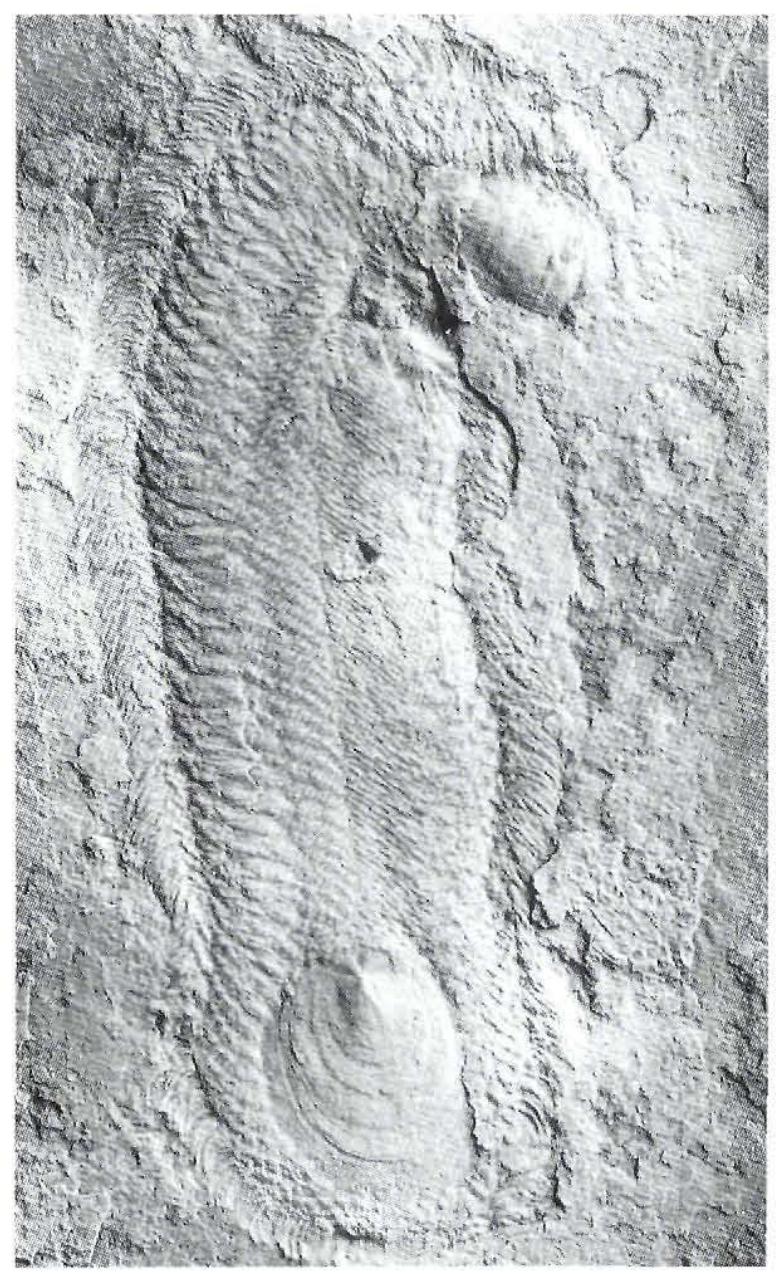




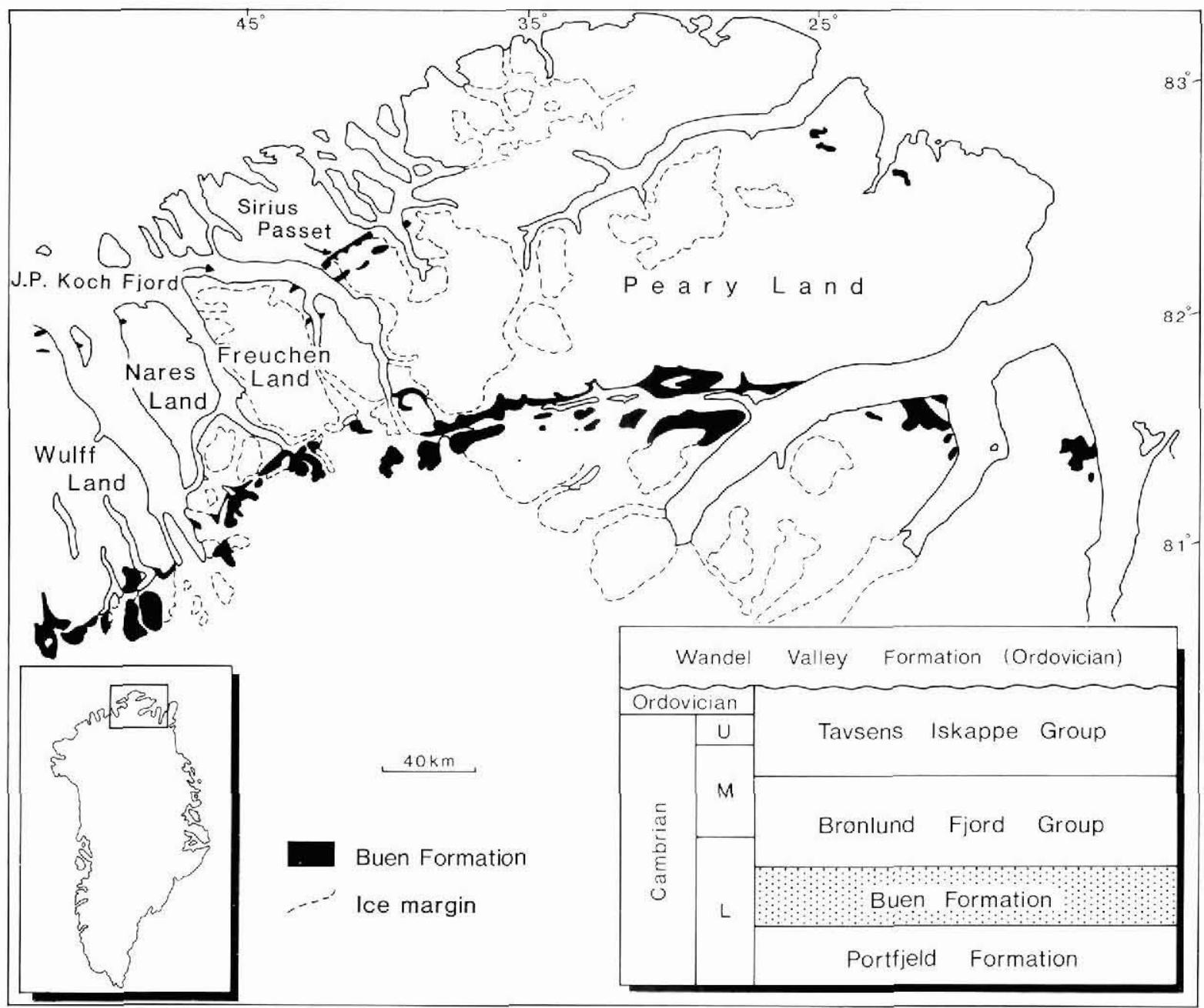

Fig. 2. Outcrops of the Buen Formation in central North Greenland showing the locality for the Lower Cambrian lagerstätten at Sirius Passet.

During July - early August 1991, a second 4-man expedition visited Sirius Passet. As in 1989, financial support for the fieldwork was provided by a grant from the Carlsberg Foundation, Copenhagen. Transport both to and within North Greenland was co-ordinated with several other groups from Danish scientific institutions under a logistic umbrella provided by Dansk Polarcenter. Three weeks of collecting benefitted from excellent weather, in contrast to the poor conditions which prevailed during the 1989 visit.

Collecting during 1991 yielded more than 3000 fossiliferous slabs and confirmed the image of the fauna established already in 1989. A number of additional specimens of halkieriids were obtained, together with numerous arthropods with preserved soft parts. Two specimens of a possible onychophoran are of particular interest on account of current discussions of the Cam- brian record of this group (Ramsköld \& Hou Xianguang, 1991; Bengtson, 1991).

Despite limitations imposed by structural complexity and intermittant exposure, fieldwork in 1991 resulted in an increased understanding of the local stratigraphy and the sedimentological evolution of the immediate area of the fossil locality. The steeply-dipping fossiliferous mudstones of the Buen Formation occur in close proximity to horizontally-bedded platform carbonates of the stratigraphically older Portfjeld Formation; this contact has been interpreted previously as a structural feature, either a down-to-basin (i.e. north) normal fault or a back-thrust (A. K. Higgins, personal communication, 1991). Detailed mapping and the occurrence, locally, of carbonate slope facies at the contact, however, suggest that the boundary defines the original northern margin of the Portfjeld Formation carbonate platform. This 
conclusion is compatible with the regional palaeogeography (Higgins et al., 1991) and implies that the fossilbearing mudstones of the Buen Formation were deposited basinward of the shelf edge, in a transitional 'slope' setting.

Thrust repetition was demonstrated within strata of the Buen Formation north of the contact with the Portfjeld Formation. Thus, minor tectonic modification of the boundary between the Buen Formation and the Portfjeld Formation can not be precluded. Preliminary correlation between the fossil-bearing, mud-dominated strata of the Buen Formation north of the shelf edge and the Buen Formation exposed in outliers on top of the Portfjeld Formation, in the area south of the edge, suggests that the former were deposited following the initial transgression of the karstified Portfjeld platform; this is compatible with the stratigraphic position of the Sirius Passet fauna suggested previously, namely within the lower part of the Buen Formation (Peel, 1990).

Acknowledgements. We thank fellow expedition member Mona Bjørklund for assistance in the field and S. Hauge Andersson (Dansk Polarcenter) for his organisational expertise. The programme received financial support from the Carlsberg Foundation, and logistic support from the Royal Danish Air Force and the Geological Survey of Greenland.

\section{References}

Barthel, K. W., Swinburne, N. H. M. \& Conway Morris, S. 1990: Solnhofen: a study in Mesozoic palaeontology, 236 pp. Cambridge: Cambridge U.P.

Bengtson, S. 1991: Oddballs from the Cambrian start to get even. Nature 351, 184-185.

Briggs, D. E. G. \& Crowther, P. R. 1990: Palaeobiology. A synthesis, 583 pp. Oxford: Blackwell Sci. Publ.

Chen Jun-yuan \& Erdtmann, D.-D. 1991: Lower Cambrian lagerstätte from Chengjiang, Yunnan, China: insights for reconstructing early metazoan life. In Simonetta, A. M. \& Conway Morris, S. (ed.) The early evolution of Metazoa and the significance of problematic taxa, 57-76. Cambridge: Cambridge Univ. Press.

Chen Jun-yuan, Bergström, J., Lindström, M. \& Hou Xianguang 1991: Fossilized soft-bodied fauna. Natl Geographic Res. \& Explor. 7(1), 8-19.
Conway Morris, S. 1979: The Burgess Shale (Middle Cambrian) fauna. Ann. Rev. Ecol. System. 10, 327-349.

Conway Morris, S. 1986: The community structure of the Middle Cambrian Phyllopod bed (Burgess Shale). Palaeontology 29, 423-467.

Conway Morris, S. \& Peel, J. S. 1990: Articulated halkieriids from the Lower Cambrian of north Greenland. Nature 345, 802-805.

Conway Morris, S., Peel, J. S., Higgins, A. K., Soper, N. J. \& Davis, N. C.1987: A Burgess shale-like fauna from the Lower Cambrian of North Greenland. Nature 326, 181-183.

Gould, S. J. 1989: Wonderful life. The Burgess shale and the nature of history, 347 pp. New York: W. W. Norton \& Co.

Higgins, A. K., Ineson, J. R., Peel, J. S., Surlyk, F. \& Sønderholm, M. 1991: Lower Palaeozoic Franklinian Basin of North Greenland. Bull. Grønlands geol. Unders. 160, 71139.

Hou Xian-guang \& Bergström, J. 1991: The arthropods of the Lower Cambrian Chengjiang fauna, with relationships and evolutionary significance. In Simonetta, A. M. \& Conway Morris, S. (ed.) The early evolution of Metazoa and the significance of problematic taxa, 179-187. Cambridge: Cambridge Univ. Press.

Müller, K. J. 1985: Exceptional preservation in calcareous nodules. Phil. Trans. Roy. Soc. Lond. B311, 67-73.

Peel, J. S. 1990: Studying the early history of life in Greenland. Rapp. Grønlands geol. Unders. 148, 54-56.

Peel, J. S. 1991: The Classes Tergomya and Helcionelloida, and early molluscan evolution. Bull. Grønlands geol. Unders. 161, 11-65.

Ramsköld, L. \& Hou Xianguang 1991: New early Cambrian animal and onychophoran affinities of enigmatic metazoans. Nature 351, 225-228.

Seilacher, A., Reif, W.-E. \& Westphal, F. 1985: Sedimentological, ecological and temporal patterns of fossil lagerstätten. Phil. Trans. Roy. Soc. Lond. B311, 5-23.

Stürmer, W., Schaarschmidt, F. \& Mittmeyer, H.-G. 1980: Versteinertes Leben im Röntgenlicht, 80 pp. Frankfurt: Verlag W. Kramer.

Whittington, H. B. 1985: The Burgess Shale, 151 pp. New Haven: Yale U.P.

J. S. P., Geological Survey of Greenland, Copenhagen.

S. C. M., Dept of Earth Sciences, University of Cambridge, Downing Street, Cambridge CB2 3EQ, U.K.

J. R. I., Geological Survey of Denmark, Thoravej 8, DK-2400 Copenhagen NV, Denmark. 